УДК 334.02

LiWei,

postgraduate student, Sumy National Agrarian University

ORCID ID: 0000-0001-9855-229X

DOI: $10.32702 / 2306-6814.2020 .4 .77$

\title{
ANALYSIS OF HIGHER EDUCATION INSTITUTIONS IN CHINA
}

\author{
$\Lambda$ і Вей, \\ аспірант, Сумський національний аграрний університет
}

\author{
АНА $І$ АІЯ АЬНОСТІ ЗАК АААІВ ВИЩОЇ ОСВІТИ В КИТАЇ
}

Local universities occupy an important position in Chinese higher education system, have made important contributions to the reform and opening up and Chinese economic development and have played an important role in promoting the popularization of higher education. There are many unfavorable factors in the development of local colleges and universities. Facing the new situation of Chinese economic transformation and upgrading of the structure of Chinese local colleges and universities faces great opportunities and challenges, this research through the methods of literature review, a detailed combing the Chinese higher education and the development of local higher education, the development present situation and existing problems, try to look for the answer to the existing problems in the development of local colleges and universities, seeking direction for the development of local colleges and universities in the future. Through this research, we believe that Chinese local colleges and universities face major opportunities and challenges in the transformation and upgrading of the national economy. China has a large population and needs a large number of high-level local colleges and universities to provide educational opportunities for them. At present, the faculty, discipline construction, teaching and research of local colleges and universities are not consistent with the current status of China's social and economic transformation and development. In the future, China's economic development requires a large number of high-level applied technical talents. Local colleges and universities should seize opportunities and achieve transformation. They should make adjustments in accordance with social development in terms of development direction selection, internal management, and discipline development. In the future, local colleges and universities in China should pay attention to the research and development, education, promotion and application of application technology for service production and life. They should emphasis on teachers' ability to translate theory into applied technology and use it in production practicing and continuously improve teachers' professional skills and comprehensive quality.

Університети в Китаї займають важливе місце в системі вищої освіти, відіграють ключову функціональну роль у сприянні популяризації вищої освіти та здійснюють важливий внесок у економічний розвиток країни. На сьогодні в досліджуваній країні існує значна кількість чинників зовнішнього та внутрішнього середовища, які, в загальній сукупності можуть здійснювати негативний вплив на діяльність зазначених освітніх інституцій. Процес розвитку китайської вищої освіти тісно пов'язаний з національним соціальним та економічним розвитком.

Мета написання статті полягає в дослідженні процесу розвитку вищої освіти в Китаї, виявленні проблемних аспектів та виокремленні заходів щодо вдосконалення організації освітнього процесу, інших рекомендацій, які сприятимуть розвитку коледжів і університетів.

На підставі проведених досліджень автор вважає, що перед китайськими місцевими коледжами та університетами постає велика кількість можливостей та викликів, які сприятимуть трансформації та модернізації національної економіки. Китай має значну чисельність жителів і потребує значної кількості місцевих коледжів та університетів для надання населенню можливості отримати повну вищу освіту. В умовах сьогодення методика викладання в коледжах та університетах дещо не відповідає поточному стану соціально-економічної трансформації та розвитку Китаю. Враховуючи той Факт, що економічний розвиток Китаю потребує значної кількості фахівців з вищою освітою, місцеві коледжі та університети повинні в обов'язковому порядку перетрансформувати освітню стратегію. Тобто заклади вищої освіти зобов 'язані провести моніторинг сильних і слабких позицій у власній освітній діяльності, реально оцінити виклики, ризики та змоделювати перспективні напрями вдосконалення діяльності. Реалізація зазначеного дозволить вдосконалити освітній процес з урахуванням сучасних інноваційних підходів, технологій, міжнародних викликів та реальних потреб, які на сьогодніє в Китаї. 
Заклади вищої освіти потребують поглибленого акценту на можливостях викладачів перемістити знання з теоретичної площини в практичну та використовувати їх під час проведення виробничих практик.

Key words: higher education, local colleges and universities, central colleges and universities, transformation and upgrading.

Ключові слова: Вища осВіта, місцеві коледжі та уніВерситети, центральні коледжі та університети, трансорормація, модернізація.

\section{INTRODUCTION}

Chinese local universities play an important role in the higher education system, but the central government does not pay enough attention to their development. The development process of local universities is closely related to Chinese social and economic development, which is the product of Chinese social and economic development and has effectively promoted the development of all aspects of China. Chinese social and economic development has entered a new stage, from the pursuit of quantity expansion and GDP upgrading to the pursuit of quality improvement and connotative development. The industrial structure of all walks of life in China is constantly transforming and upgrading, which requires local colleges and universities to adapt to the situation, choose a good positioning, adjust development strategies.

It is suggested that the national administrative departments at all levels attach importance to the development of local colleges and universities, provide human, financial, material and policy support for the development of local colleges and universities, promote the rapid development of local colleges and universities in the process of transformation and upgrading and continue to train more and more excellent talents for the new stage of Chinese economic and social development.

\section{LITERATURE REVIEW}

Many scholars have been committed to the research on the development of higher education and local higher education in China and have formed their own research results: Lei Hongde, Xu Ping, Zhang Jie, Shi Xiaoyu, Xie Genxing, Ge Chen, Fang Zeqiang, Chen Jian and others.

Through literature reading and interview research, we find that Chinese colleges and universities, especially local colleges and universities, have a great influence on the development of social economy. We should pay attention to the related research on this topic and conduct more indepth and comprehensive research along this direction.

\section{THE PURPOSE OF THE ARTICLE}

The purpose of this study is to investigate the development process of higher education in China, discover problems in its development, and propose improvement measures and recommendations to promote the development of colleges and universities.

\section{THE MAIN RESULTS OF THE RESEARCH}

The development process of Chinese higher education is closely related to the national social and economic development. The development of local colleges and universities has made great contributions to Chinese reform and opening up. The development of local colleges and universities should take into account Chinese economic development, seize opportunities and realize their own transformation and upgrading. Applied technology talents are urgently needed in the future development of China. Local universities should attach importance to the development of applied technology field and transform and upgrade into applied technology universities.

Chinese local colleges and universities have made special contributions to the economic construction and social development. Relying on the scientific and technological advantages they promote the local scientific and technological progress. They provide various services for local social development and promote local social and economic development.

Lei Hongde divides the historical development of Chinese higher education into three stages: from the legendary five emperors to the end of the Qing dynasty was the "humanistic" stage; Nearly a century was the "science" stage; Now we are in the "humanistic and science" stage [1]. Xu ping divided Chinese higher education from 1949 to the present into four stages: From the founding of the People's Republic to 1958 (learning from the Soviet union); 1958-1966 (period of stable development after breaking away from the Soviet model); 1966-1978 (period of unrest and stagnation); 1978-present (rapid development stage) [2].

Since the 1980s, Chinese economy and society have been changing a lot and the system and structure of higher education have been adjusted. In order to meet the demand for talents in Chinese reform and opening up, the Ministry of Education of China issued "Action plan for education revitalization for the 21 st century" in 1999, which proposed that by 2010 , the total admission rate of higher education would reach $15 \%$ of the school-age youth. After 40 years of development since the reform and opening up, the scale of higher education in China is the first in the world.

The total number of Chinese higher education students is shown in Figure 1.

Total admission rate of higher education (Figure 2).

In 2018 China enrolls 858,000 postgraduates, including 739,300 full-time students. It has enrolled 95,500 doctoral students and 762,500 master's students. There are 2.7313 million postgraduate students, including 389,500 doctoral students and 2.3417 million master students. There were 604,400 graduate students, including 60,700 doctoral students and 543,600 master's degree students [11].

According to the research of American scholar Martin Trow, according to the total admission rate of higher education, the development process of higher education can be divided into three stages: "elite, mass and universal". When the total admission rate of higher 
education is less than $15 \%$, higher education belongs to the stage of elitism. When it reaches 15\%-50\%, it is the mass stage. When it reaches above $50 \%$, it is the universal stage. It means that Chinese higher education has entered the stage of popularization from the massification stage.

The enrollment of postgraduates in Chinese higher education continues to expand. There are nearly 2,64 million postgraduates in China, and nearly 580,000 graduates every year. These indicators indirectly prove that the development of higher education in China not only makes progress in quantity, but also attaches great importance to the improvement in quality.

The main problems of higher education in China are as follows: the absolute amount of higher education is large but the proportion is low. The educational structure of teachers is unreasonable. The ratio of students to teachers is high. The scientific research is developing rapidly, but the funds and staff are limited. The contribution rate to the economy is low.

According to the school-running system, Chinese universities and colleges can be divided into public, private and independent universities and colleges. Public universities and colleges refer to those established and maintained with the support of the national government or local government. They can be divided into three types: ministerial, provincial and municipal universities and colleges. To sum up, local colleges and universities refer to those institutions of higher learning that are subordinate to provinces, autonomous regions, municipalities directly under the central government, Hong Kong and Macao special zones, and most of them are supported by local finance and funded by local administrative departments.

Statistical reports on the number of universities in China in 2018 are presented in Figure 3.

As can be seen from Figure 3, with the continuous development of Chinese reform and opening up, Chinese local colleges and universities undertake the important task of training and conveying all kinds of talents, in this process, the scale of local colleges and universities is rapidly expanding.

From table 1, among all kinds of colleges and universities, income, expenditure and surplus of local colleges and universities account for an important proportion. This shows that the total financial revenue and expenditure of local colleges and universities is larger in the whole country.

Comparison of per capital expenditure of students in local universities and central universities is presented in Figure 4.

However, in recent years, Chinese central government pays more attention to the development of key schools and disciplines. In order to promote the development of higher education and promote the progress of science and technology in China, the state has successively carried out the "211" plan, "985" plan, "double firstclass" construction plan and other state support plans for the development of key universities and disciplines and further guided the concentration of superior

60
Total number of students

( Ten thous ands)

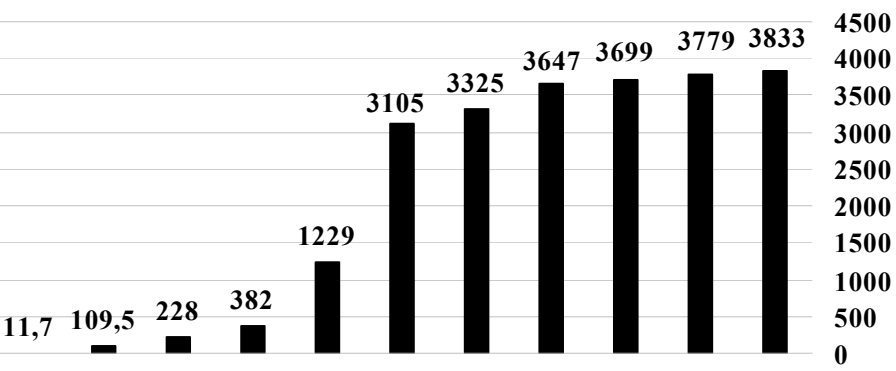

19491965197819902000201020122015201620172018

Figure 1. Total number of students of higher education [3]

Total admission rate (\%)

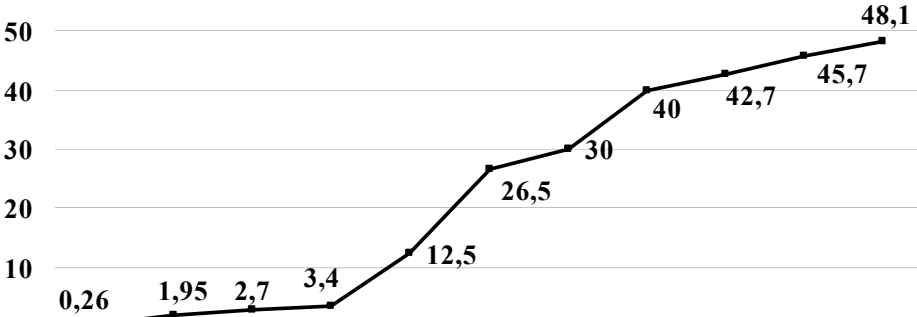

$\begin{array}{lllllllllll}1949 & 1965 & 1978 & 1990 & 2000 & 2010 & 2012 & 2015 & 2016 & 2017 & 2018\end{array}$

Figure 2. Total admission rate of higher education [3]

Statistics on the number of universities in China (2018)

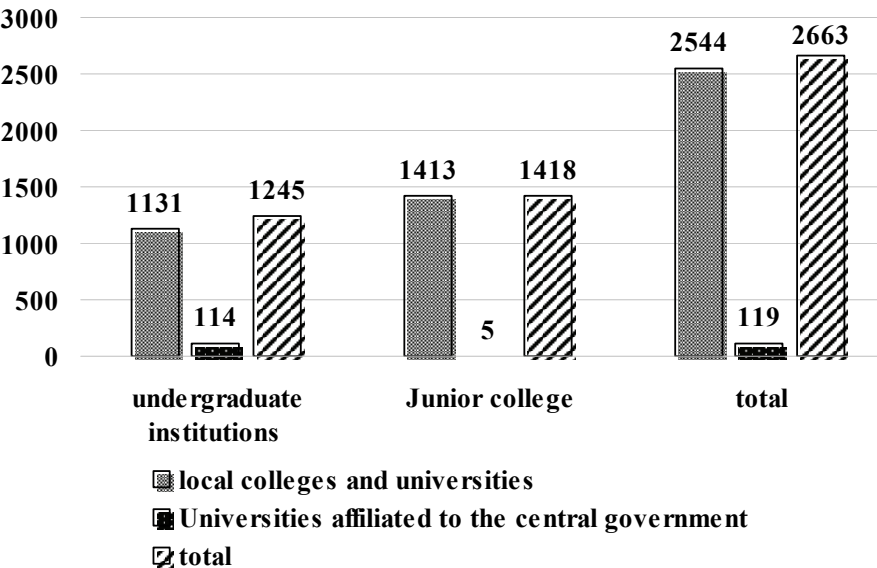

Figure 3. Statistics on the number of universities in China (2018) [11]

resources in key national universities, among which local universities have less chances (Figure 4).

From table 1, although the financial surplus of local universities accounts for nearly $58 \%$, the number of local universities accounts for more than $95,5 \%$, so the average financial surplus of each local university is little.

Table 1. Comparison table of financial situation of Chinese colleges and universities (unit: 1000 yuan) [4]

\begin{tabular}{|l|l|c|c|}
\hline \multicolumn{1}{|c|}{ School category } & \multicolumn{1}{c|}{ Income } & Outcome & Surplus \\
\hline Total & 1012464513 & 939684529 & 72779984 \\
\hline Local colleges and universities & 710310096 & 668134038 & 42176058 \\
\hline
\end{tabular}


Education expenditure

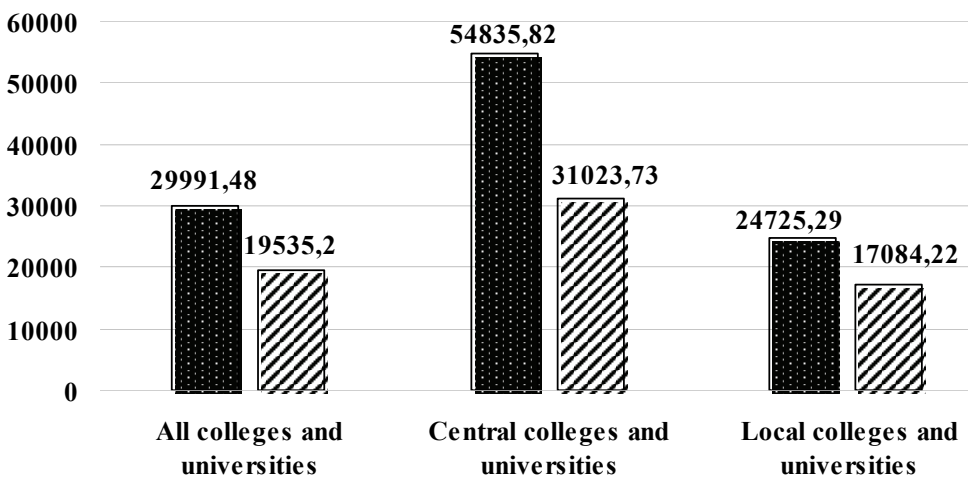

Education expenditure per student

4. Public finance budget education expenditure per student

Figure 4. Comparison of per capital expenditure of students in local universities and central universities [4]

Chinese economic development has changed from pursuing quantity to focusing on quality, and most local universities are facing the transformation. Local colleges and universities, especially those in transition, need to adjust their development ideas, pay attention to the reserve of applied technical talents in the management of teacher introduction, training and assessment, and make targeted adjustments to the structure of teachers' ability [5].

China has a large population and needs a large number of local universities to provide them with educational opportunities. Local universities play an important role in the higher education system. The development strategy of local universities in China must be adjusted according to the changes of social and economic development.

With the social and economic development and the industrial transformation and upgrading in China, in the future, most local universities in China should pay attention to the reserve and introduction of applied technologyoriented teachers, so as to meet the needs of social and economic development.

\section{CONCLUSIONS}

As Chinese social and economic development entering a new stage, the development of higher education should adapt to the new situation of social and economic development. In my opinion, firstly, we need to develop high-level universities and disciplines and train world-class talents and technologies for our country. The second is to attach importance to the practical application value of higher education and train a large number of applied technical talents for the national economic and social development.

Based on this study, we propose the following suggestions for the development of China's higher education. First, Chinese colleges and universities should seriously study the optimization and upgrading of the national industrial structure and their own positioning, and combine school development with national development strategies. Secondly, the central universities should be committed to the world's leading scientific and technological research and provide technical support for the country's economic and social development. The third, local colleges and universities should pay attention to the cultivation of applied technical talents and at the same time provide on-the-job training and opportunities for the workers to adapt their talents to the needs of the optimization and upgrading of the national industrial structure. The fourth, colleges and universities should adjust its own discipline setting, professional development, teacher standards, management methods and other aspects in line with the national development strategy.

In the past, Chinese local universities have cultivated a large number of talents for the rapid development of the social economy and they have also achieved rapid development. With the economic development from the pursuit of increasing quantity to focus on the quality of upgrading, the local colleges and universities also need to make strategic adjustments. Chinese economy and society are undergoing industrial restructuring and China needs a large number of highquality applied technicians in the future. Local universities should adapt to the development situation, seize the opportunities.

\section{References:}

1. Lei Hongde, (2001), "Three stages of the historical development of higher education in China", Journal of Heilongjiang higher education research, vol. 6, p. 40-41.

2. Xu Ping, (2013), "A brief introduction to the development history of higher education in contemporary China", Journal of Shang Qing, vol. 52, p.187-187.

3. The development of higher education in China. URL: http://www.moe.gov.cn/

4. Finance department of Ministry of Education of China, (2017), China education expenditure statistical yearbook, China statistics press, Beijing, China.

5. Zhang Jie, (2010), Development reality and ideal of local universities, Central China normal university press, Wuhan, China.

6. Shi Xiaoyu, (2019), "Research on human resource management in local universities in China", Journal of Modern marketing (information edition), vol. 5, p.198.

7. Xie Genxing, (2019), "Reflections on teacher management in local universities", Journal of minnan normal university (philosophy and social sciences edition), vol. 33 (1), p. $126-130$.

8. Ge Chen, (2017), "A brief analysis of scientific research management in local universities", Journal of Science and technology information, vol. 15 (29), p. 155-156.

9. Fang Zeqiang, (2019), "Teacher development in local universities: problems and countermeasures", Journal of shijiazhuang university, vol. 21 (4), p. 127-130.

10. Chen Jian, (2017), "Discussion on transformation of local universities", Journal of Science and education guide (electronic edition), vol. 22, p. 40.

11. The development of higher education in China. URL: http://www.moe.gov.cn/.

12. Basic information of higher education, (2019), China education statistics yearbook, China statistics press, Beijing, China.

Стаття надійшла до редакиії 25.02.2020p. 